\title{
A VEGETATION ANALYSIS OF A PIMPLED PRAIRIE IN NORTHEASTERN OKLAHOMA
}

\section{A thesis for the Department of Life Sciences The University of Tulsa 1974}

\author{
Constance Lucile Murray \\ Current address Tulsa Community College
}

The effect of pimple mound microrelief on the vegetation of a tall grass prairie was considered. Taxonomic analysis of the vegetation affirmed the observation that mound and intermounds support communities with differing species composition. The difference in the percent cover by living vegetation on mounds and intermounds was determined not to be statistically significant. The physical composition of the soil in the two regions was found to be similar. Two factors are suggested as influencing the differences in mound and intermound vegetation: that mound soils can provide more available water to plants than can intermound soils, and that mounds, but not intermounds, contain the burrows of small mammals and are modified by their presence.

INTRoDuctron
Pimple Mounds are low,
regular domes of soil that
establish a microrelief
pattern common on prairies
in eastern Oklahoma (Figs.
1, 2). Similar mounds occur
throughout the United States
(Fig. 3), on both level and
gently sloping terrain
(Knechtel 1952). Mounds have
also been described from
South America (Scheffer
1958) and Australia
(Prescott, 1931). They are
variously called natural
mounds and hog wallow relief
in California (Branner,
l905), Mima mounds in
Washington (Dalquest and
Scheffer, 1942), and pimpled

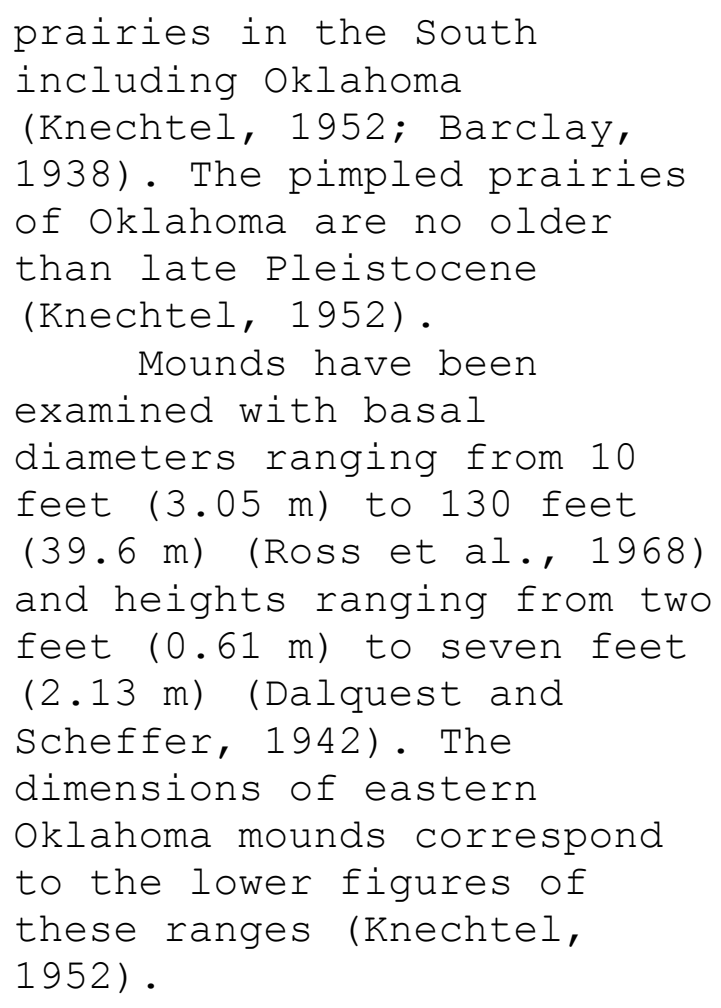




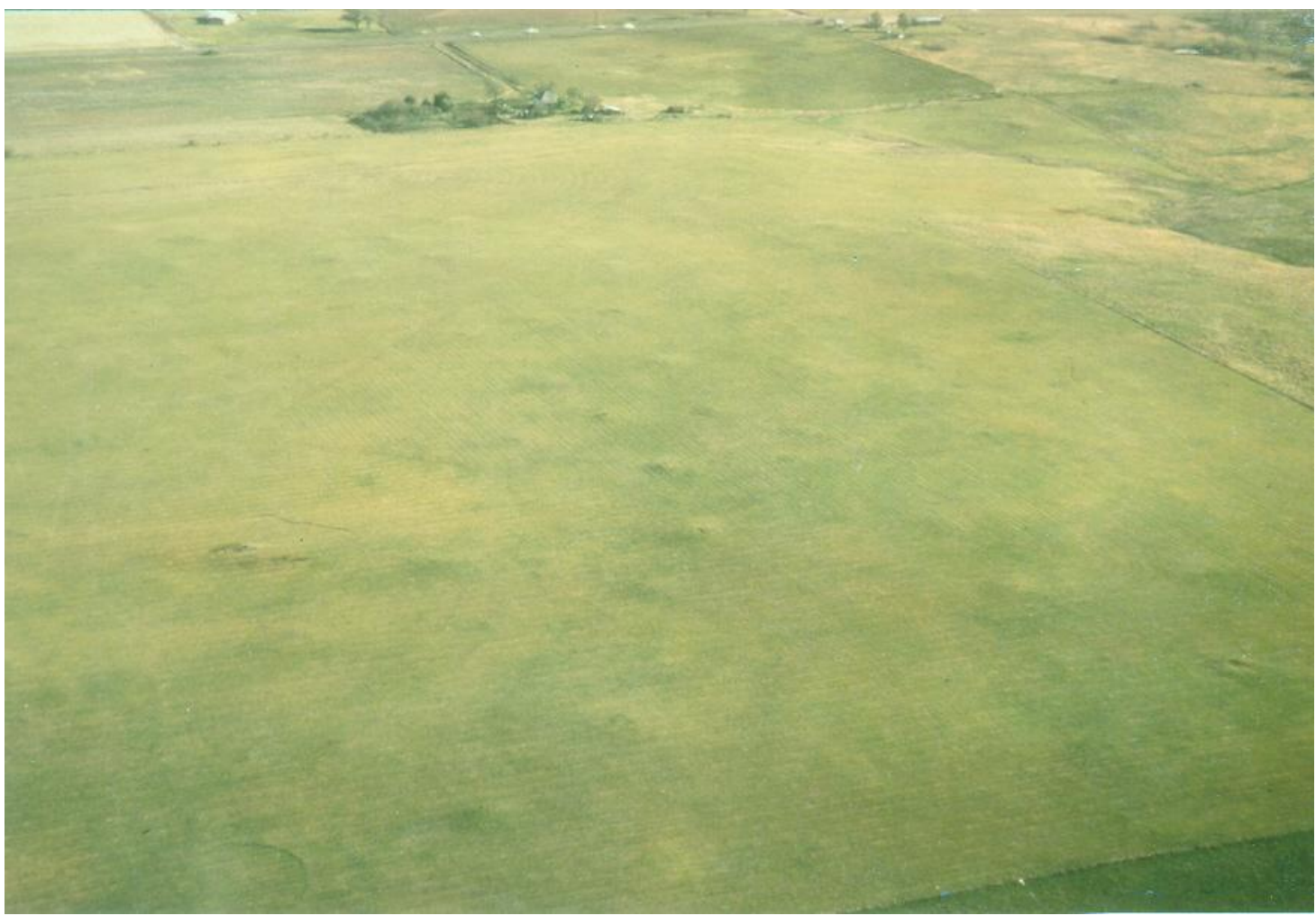

Figure 1 Study site showing pimpled microrelief, April 1972

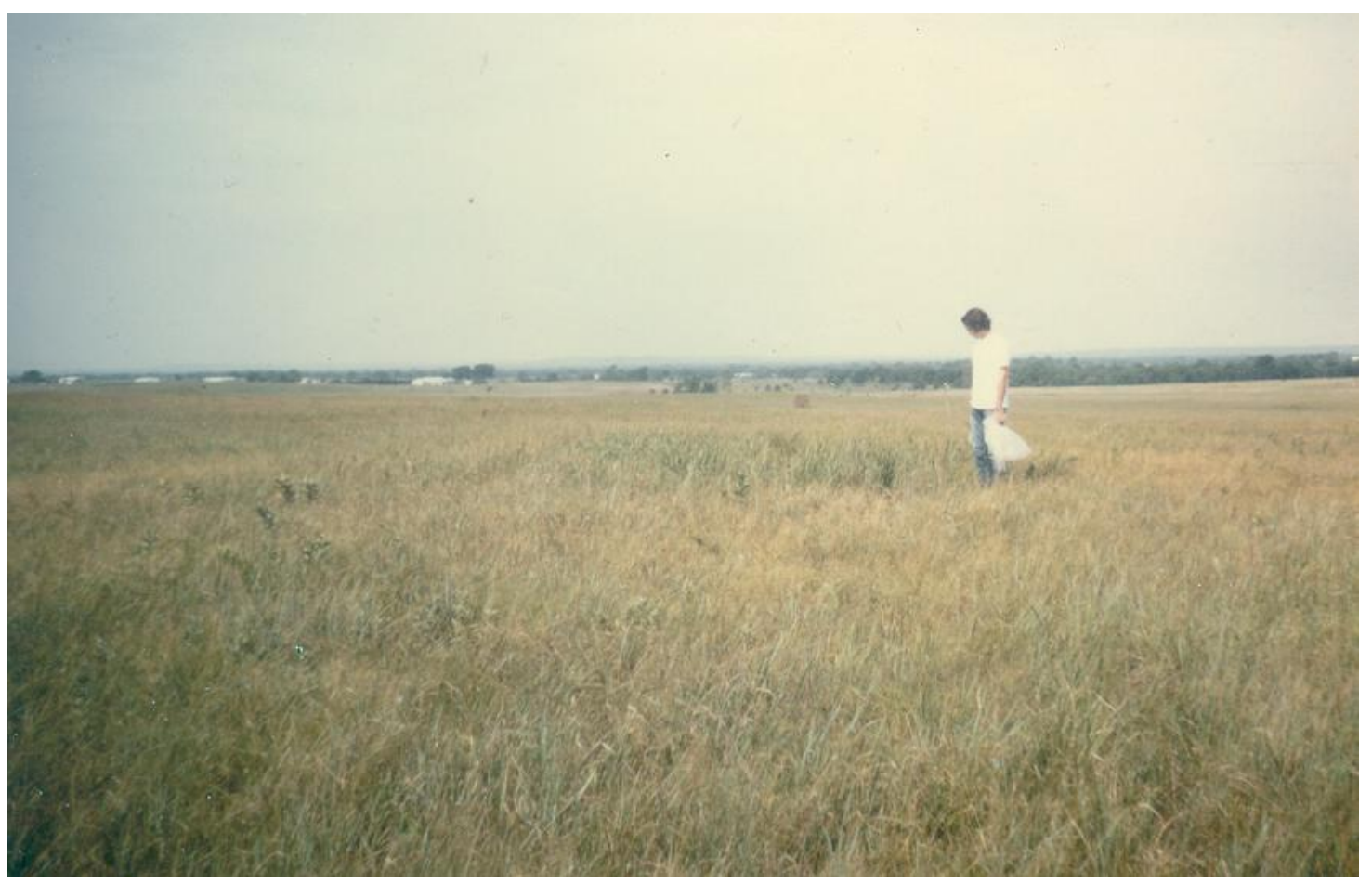

Figure 2 Pimple mound, demonstrating greener vegetation than the surrounding prairie, late June 1972

Murray, C.L. 
Pimple mounds typically consist of unstratified soil, variously characterized as "loesslike" (Knechtel, 1952) or extremely loose and friable (Ross et al., 1968); this dark material is responsible for most of the height of the mound and often rests on a clay pan which is lighter in color (fig. 4). Between the mounds is an intermound furrow system. The interface between the soil and the subsoil does not demonstrate the pimpled microrelief; thus the mounds are features of the soil and not of the underlying strata; the soil of mound and intermound areas is similar in texture and composition (Melton, 1954 ).

Reference in scientific literature to natural mounds

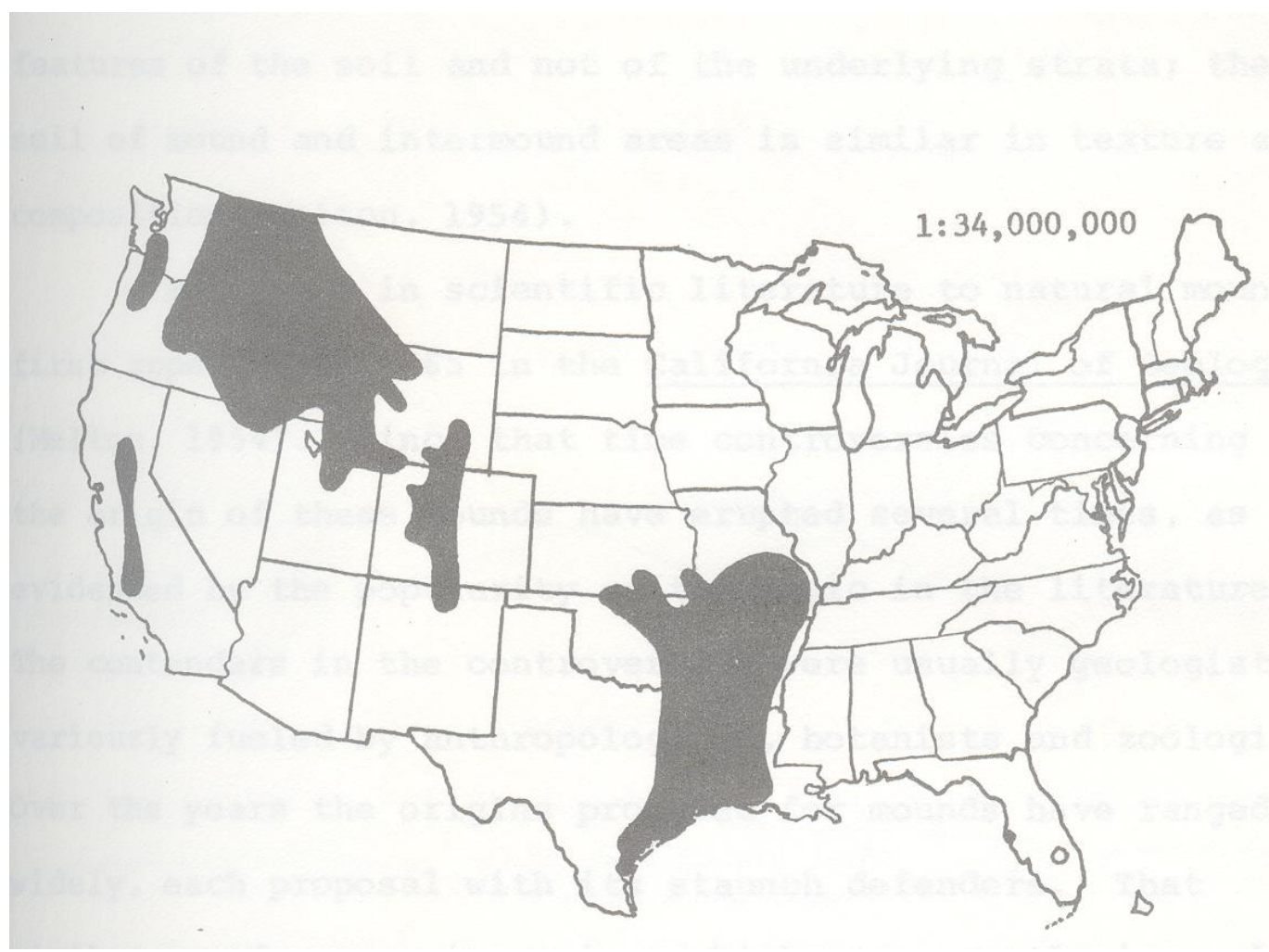

Figure 3 Shaded areas indicate the major regions in which pimple mounds occur in the United States (after Fenneman, 1931) 


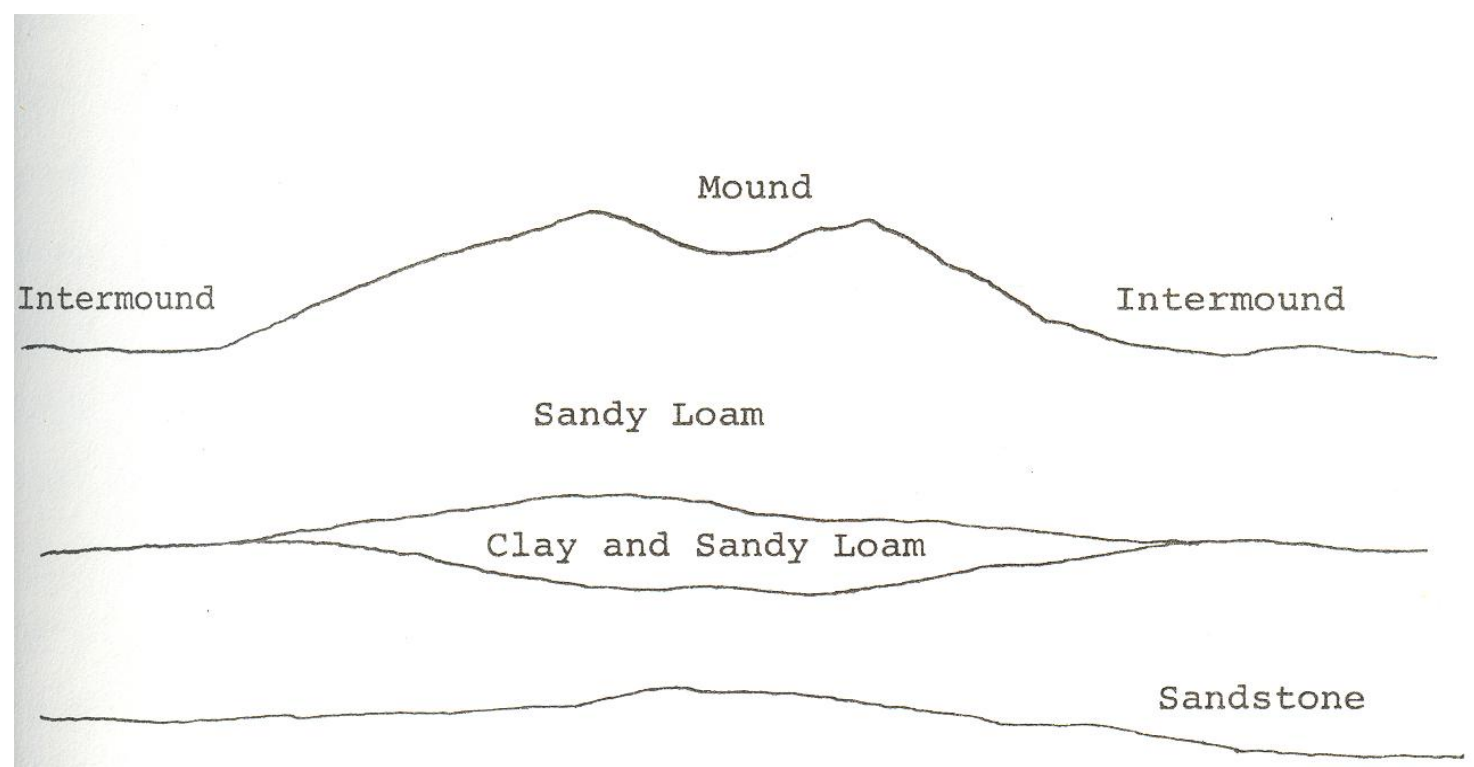

Figure 4 stylized profile of a mound showing general shape and distribution of soil types. Note depression in mound center, probably due to disturbance by small mammals. Composite sketch from various authors (Scale 1:90)

Murray, C.L. 
first appeared in 1865 in the California Journal of Geology (Melton, 1954). Since that time controversies concerning the origin of these mounds have erupted several times, as evidenced by the popularity of the topic in the literature. The contenders in the controversies were usually geologists, variously fueled by anthropologists, botanists and zoologists. Over the years the origins proposed for mounds have ranged widely, each proposal with its staunch defenders. That fact that similar mounds occur in regions which vary greatly in geologic history, present geologic forces, climate, and flora and fauna has made it difficult to ascribe one origin to all mounds, as most authors have attempted to do. A discussion of the more prominent scientific hypotheses advanced for the origin of pimpled mounds is in order.

Campbell (1906) reviewed the suggestion that the pimple mounds were Indian burial mounds; the artifacts which usually characterize such sites have been found in a few mounds excavated in the South. However, artifacts are absent in most of the mounds throughout the country (Melton, 1954). Veatch (1906) proposed that ants or termites construct pimple mounds. The town ant, Atta texana, may create soil mounds in the south (Cain, 1974). These mounds are smaller in height and larger in diameter than typical pimple mounds; ants do not inhabit mounds in other regions of the country and evidence of previous occupations has not been found (Melton, 1954).

Some authors have

suggested that mounds result from animal disturbance of an area. Dalquest and Scheffer (1942) and Scheffer (1958) asserted that, over long periods of time, pocket gophers; both recent and historic, form pimple hills. Ross et al. (1968) extended this view to include toads, ground squirrels and badgers as mound constructors. The primary basis for this proposed origin was, in each instance, the modified soil characters, i.e., lower bulk density, lack of soil structure, increased water permeability and particle size in mounds, when compared to the surrounding prairie. These authors maintain that these changes are possible with the normal activities of the suggested animals. Grant (1948) systematically discredits this proposal; his rejection of the hypothesis is based on the subjective interpretation of the pocket gopher behavior and the inconsistencies in 
Scheffer's assertions. It seems reasonable that, rather than constructing a mound to avoid a high water table, as Ross et al. (1968) suggest, rodents utilized an existing mound structure, formed by some other means. A series of physical explanations for the creation of pimple mounds has been advanced, including suggestions that the mounds: are coppices or sand dunes; result from fossil mud lumps; are protected from erosion by cap rock; are the work of glaciers; are concretionary depositions of minerals from ground water; results from spring and gas vents. Melton (1954) discussed these and other at length, discrediting each as an origin which is generally applicable, though each may have influenced mound formation in a specialized locale.

Two physical hypotheses of pimple mound origin are noted as widely acceptable; both are based on the observation that pimple mounds are found in regions with at least a moderate rainfall. Krinitsky (1949) proposed that mounds are deposited by river currents during periods of high water, forming ridges; vegetation invades when the water recedes, establishes a soil and maintains the mound. This proposed origin is supported by observations that mounds lack the well defined soil profile common in prairies, and that mounds are often found along ridges; however, Cain (1974) asserted that mounds do not occur along creeks or rivers or in alluvium. Erosion is one of the simpler and more popular explanations for soil mounds (LeConde, 1974); Melton, 1929); Knechtel, 1952, Cain, 1974). Knechtel (1952)

proposed that erosion is preceded and enhanced by the division of soil into prismatic blocks, due to seasonal desiccation and freezing. The blocks would then be worn down and rounded by erosion to produce pimple mounds. Melton (1954) suggested that weak, sandy soil erodes readily to produce gullies with walls which collapse easily and are rounded by rain and slumping to produce mounds. Aronow (1972)

favored a two-phased formative process; firstly, a pluvial period marked by high run-off to initiate mounds; secondly, a period of low rainfall and high local winds, so that vegetation on the mounds traps the blowing soil, thus creating the thick A-horizon which is characteristic of pimple hills. Cain (1974) postulated that erosion around tree cover produces pedestal trees; with demise of the trees, the eroded tree pedestals remain, forming small pimple mounds.

Murray, C.L. 
Melton (1954) concluded that one is brought by default to erosion as the creative force behind pimple hills, since none of the other proposed phenomena is sufficiently widespread or continuous to account for the number of pimple mounds. The vegetation of pimpled prairies has been examined and analyzed by several workers who provide varying descriptions. Melton (1954) discussed and concurred with Campbell's (1906) observations; both ascribed to intermounds a greater fertility, evidence by a darker color, higher water content, and higher stands of vegetation when compared to mounds. McGinnies (1960) took the opposing view that mounds are more fertile. He documented this assertion with experimental results of the herbage production of five species of grasses on mounds and intermounds in Colorado. McGinnies found that mounds yielded twice the dry weight herbage of the intermounds. Ross et al. (1968)) observed that prairie mounds were dominated by either shrubs, forbs, or grasses, depending on the size of the mound and the amount of soil disturbance by animal burrowing. Barclay (1938) reported some difference in the species of plants which occur on the mounds and intermounds in southeastern Oklahoma; notably, the genus Drosera occurs only between the mounds.

The purpose of this investigation was to study the effect of pimple mound microrelief on vegetation, particularly on species composition and on percentage cover. The study site selected is a tall grass prairie in the Cherokee Prairie Biotic District of Blair and Hubbell (1938). The prairie is approximately two miles West of Inola and four miles East of the Verdigris River on Oklahoma Highway 33, NW 1/4, S6, T 19N, R17E, Rogers County, Oklahoma (Fig. 5). At the time of the study the prairie was owned by $\mathrm{K}$. V. Spainhower, who assured the author that for more than sixty years the prairie had been mowed but neither grazed nor plowed. This prairie was thus deemed to be in an undisturbed state, when compared to other sites available for study, and particularly amenable to a vegetation study. 


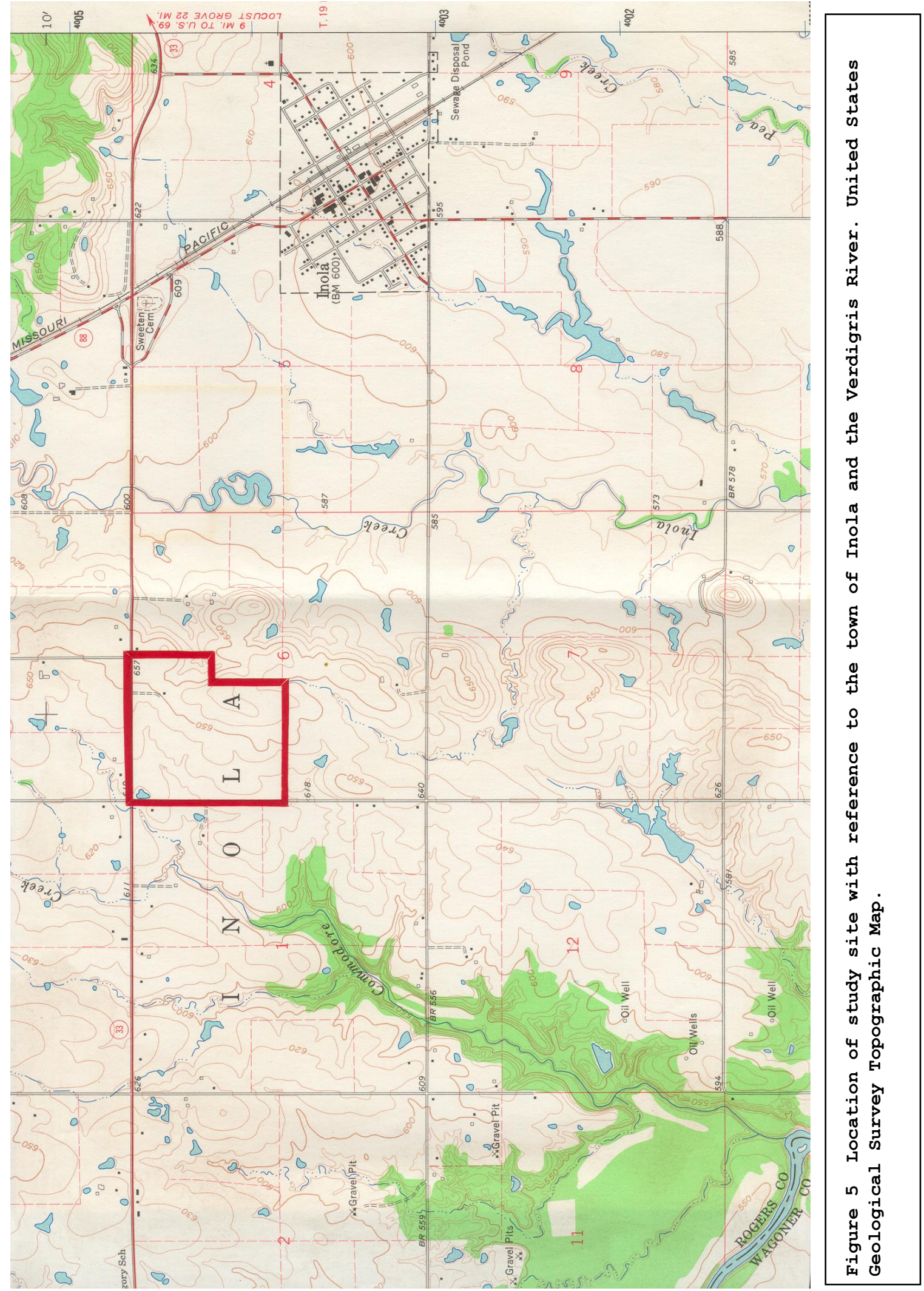

Murray, C.L. 


\section{METHODS AND MATERIALS}

The vegetation of mounds and intermounds was analyzed by the inclined point quadrat method (Tinney et al., 1937) using the basal contact modification (Whitman and Siggeirsson, 1954). The method was applied to each pimple mound in the following manner. The point frame was placed halfway up the eastern slope of a mound and readings taken from the ten pins; then the frame was moved five paces in a clockwise direction, again placed on the mound slope and read. This procedure was repeated ten times for a total of one-hundred points per mound. The different positionings of the frame formed a pattern which resembled the spokes on a wheel.

Similarly, data were gathered from the intermound region, which concentrically surrounded each mound considered. The frame was again positioned ten times, at ten pace intervals, providing one-hundred points per intermound region sampled.

Data were collected from eighteen mounds and intermound areas using the point frame, in April, June and July, 1972. The mounds considered were selected randomly. These data were tabulated and used to determine percentage cover by vegetation.

Vascular plants of the study site were collected weekly, from mid-march to mid-July, 1972; when possible, plants were collected while blooming. Nomenclature follows

Waterfall (1969). Upon collection, it was noted whether each species occurred on mounds, intermounds, or both. All plant specimens are contained in The University of Tulsa Herbarium.

The spatial

relationship between the mounds on the prairie was mapped. The fence marking the southern boundary of the study site was designated as the primary reference line; mounds were mapped in relationship to this fence. The information for the map was obtained using a Brunton compass, corrected to true North. The heights of the mounds were measured in relation to each other and to the intermound surface. The slope of the intermound surface was also measured with the compass, and distances between the mounds with a metal tape.

Soil samples were collected from the surface to bedrock, from three mounds and corresponding intermound areas, using a hydraulic soil auger two inches in diameter. The auger was provided and 
operated by Doc Polone of the Rogers county Soil

Conservation

Service, Claremore,

Oklahoma. Soil cores

collected in this manner

were placed intact in

troughs made of plastic

pipe; the pipes, 2.5 inches

$(6.4 \mathrm{~cm})$ in diameter, had

been split lengthwise to

accommodate the samples.

Soil horizons were

identified as definitively

as possible, considering the

color and macroscopic

character of the soil. Fifty

grams of soil from each

horizon was characterized as to its physical composition, percentages of sand, silt and clay, by the hydrometer method (Bouyoucos, 1936).

The climatological data presented were provided by the United States Weather Bureau Office at Tulsa International Airport. Precipitation is based on records dating back to 1950 (Curry, 1970).

The statistical tests used were the point biserial correlation to analyze the percent cover data (Downie and Heath, 1974); and the two-factor mixed design analysis of variance to analyze the data relating to the physical composition of the soils (Winer, 1962).

\section{RESULTS}

Seventy-six species of vascular plants were collected from the study site. This collection represents a total of twenty-eight families and sixty-three genera; species are listed phylogenetically in Table I. From this collection, twenty-five species (33\%) were found only in mound habitats, twenty-nine species (38\%) were collected only from intermound habitats, and twenty-two species (29\%) occurred in both habitats. This relationship between species and habitat is presented in Table II. Of the species common to both habitats in the prairie, seven species (33\%) were grasses; one-half the grasses were restricted to one habitat or the other. Percent cover of the prairie by living vegetation in the two habitats is compared in Fig. 6. The percent cover value presented for each date is the mean value for the data collected on that date. By inspection, the data reveal that higher values of percent cover were obtained for mounds than for intermounds. This information was submitted to the point biserial

statistic. The $t$ statistic indicated that the relationship between the type of terrain, i.e., mound or intermound, and the percent cover values was not statistically significant $t$ $=1.64, d f=32, p<.10)$. The low precipitation for the period preceding and

Murray, C.L. 
during this study in 1972 is presented and compared with that of the previous twenty years in Fig. 7.

The spatial

relationship between the pimple mounds on the prairie considered in this study is shown in Fig. 8. The mounds were found primarily along a ridge, from which the prairie sloped westwardly with approximately 10\% slope. In this prairie the mounds ranged from 16 feet $(4.876 \mathrm{~m})$ to 50 feet $(15.24$ $\mathrm{m})$ in diameter and from 1.5 feet $(0.457 \mathrm{~m})$ to 3.0 feet $(0.914 \mathrm{~m})$ in height. Mounds varied in shape from irregularly eggshaped [40 feet $(12.19 \mathrm{~m})$ by 50 feet $15.24 \mathrm{~m})$ ] to nearly circular [26 feet $(7.924 \mathrm{~m})$ by 27 feet $(8.229 \mathrm{~m})]$. There was generally noted a slight alignment down slope. Soil depth and the approximate thickness of each horizon from three mounds and corresponding intermound areas are compared in Fig. 9. The physical composition of the soil from each horizon is summarized in Table III. The difference in the amount of sand in the three horizons was statistically significant $(\mathrm{F}=6.999 ; \mathrm{df}=$ $2.8 ; p<.02)$. Horizon $\mathrm{C}$ had less sand than either $A$ or B. The difference in the amount of silt at the three horizons was statistically significant $(F=47.794 ; d f$ $=2.8 ; p<.001)$. Horizon A had more silt than either $B$ or $C$. The difference in the amount of clay in the three horizons was statistically significant $(\mathrm{F}=7.335 ; \mathrm{df}=$ 2.8; $p<.02)$. Horizon $\mathrm{C}$ had more clay than either A or B. When comparing soil from mounds with that of

intermound areas, the difference in the percentages of sand, silt and clay was not statistically significant (Sand: $F=1.813 ;$ df $=1.4$; $p<.25),($ Silt: $F=3.460$; $d f=1.4 ; p<.15),($ Clay: $\mathrm{F}$ $=1.041 ; d f=1.4 ; p<.4)$.

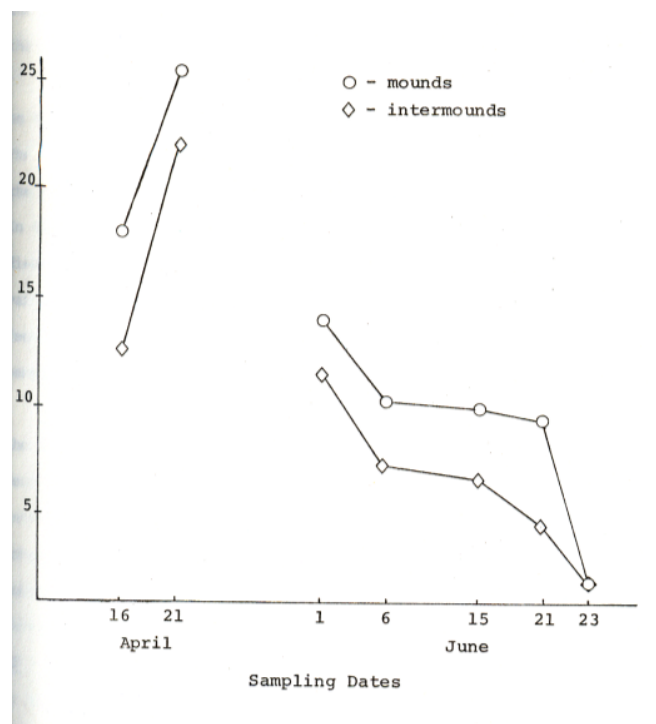

Figure 6 The percentage of cover by living vegetation of mounds $(0)$, and intermounds $(<>)$, determined with a point frame, basal contact modification. 


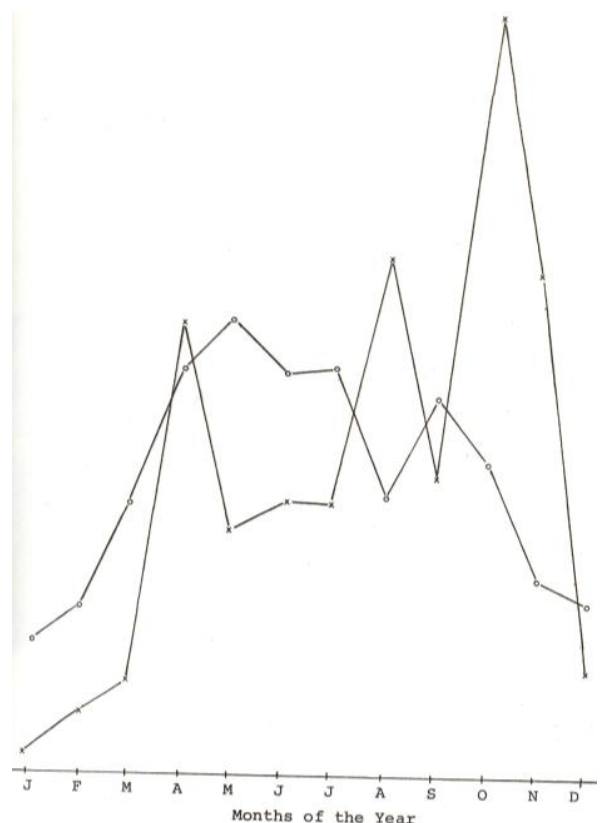

Figure 7 Monthly precipitation figures for 1972 (x), compared with monthly means calculated from 19511970 (o) for Tulsa County. From U.S. Weather Bureau.

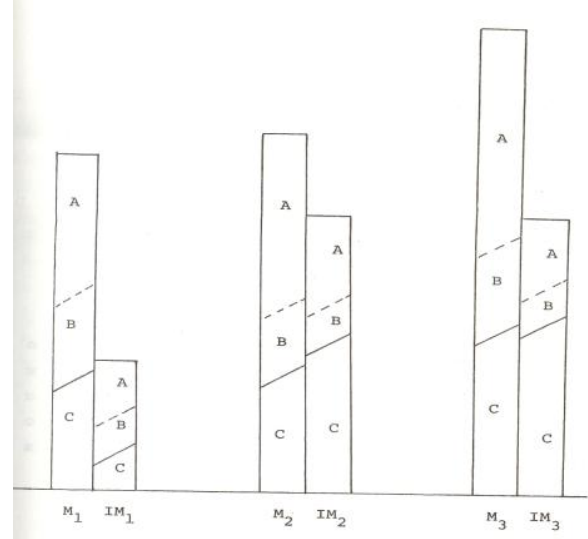

Figure 9 Comparison of soil depths and soil horizons for three mounds and corresponding intermound regions.

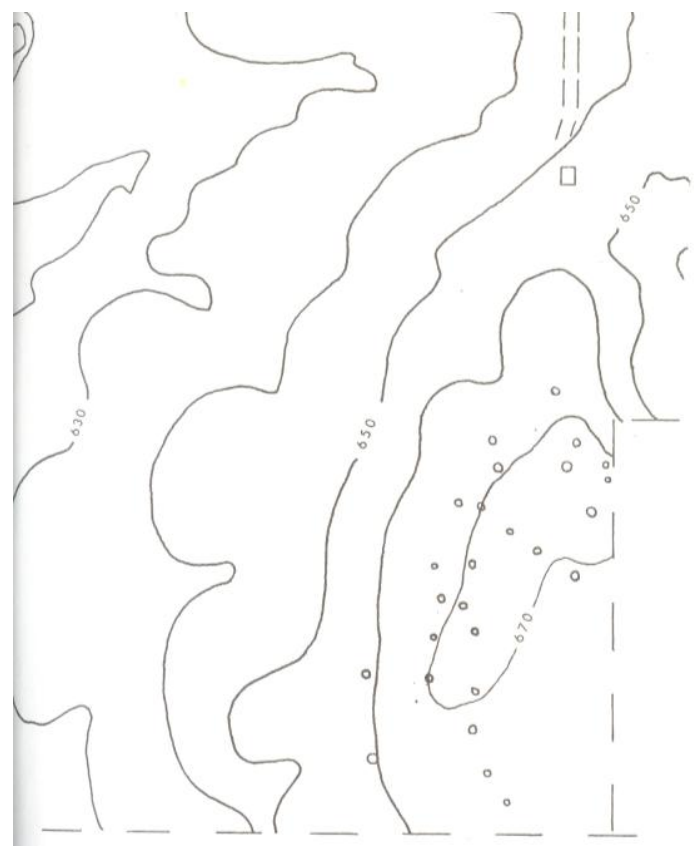

Figure 8 Distribution of mounds in the prairie studied. Note that the distribution pattern generally follows the higher contour lines. (Scale $1: 17,352$ )

\section{DISCUSSION}

One factor to be considered to interpreting the data presented is the distribution of the rainfall for the duration of the experiment; for this period, the precipitation was lower than average which produced a marked effect on the vegetation. Many plants appeared vegetatively but growing tip shriveled and turned brown before flowers bloomed; therefore, many of these plants were not identified. It is possible that the low rainfall for this early summer period reduced the number of species recorded for the prairie. 
In both mound and intermound habitats the small forbs dried in May and June, leaving a vegetation consisting mainly of grasses. Although this phenomenon is common in prairies, it usually occurs later in the growing season and after plant reproductive cycles have been completed. This early desiccation of the prairie and its vegetation is reflected in the percent cover figures, which steadily decreased through June until cover was recorded as one percent in mid-June (Fig. 6) . Generally, the intermound vegetation evidenced desiccation before that on the mounds. The low rainfall may have accentuated the difference recorded in mound and intermound vegetation cover, which will be discussed later. The rainfall is probably partially responsible for the low range of percent cover when these figures are compared to those of other studies (Drew, 1944); Whitman and Siggeirsson, 1954 ).

The method of plant collection rendered the information unsuitable for statistical analysis of the interaction between species occurrence and habitat (Table II). Upon inspection, there is no obvious distribution of certain families to either mounds or intermound regions. It is noted that some genera within a family and some members of a genus were distributed, one in mound habitats, another in intermound habitats. The distribution, as recorded, reflects the interaction of the microhabitat conditions most favorable to each species. Determination of these conditions would require extensive research on the physiological growth requirements for each species. As mentioned above, some species never bloomed, due to drought; perhaps in a more pluvial year, when a greater number of representatives from each family bloomed, more conclusive remarks could be made about the distribution of plant families in the mound and intermound habitats. Analysis of the difference in the percent cover data of mounds and intermounds revealed this difference to be statistically insignificant (Fig.6). Thus it is concluded that the variation of the percent cover was possible due to chance alone, and that the vegetation on mounds and intermounds is one plant population, not two. The inclined point quadrat method was used in this study with the basal contact modification, attempting to reduce the quantity of data and yet provide an accurate 
assessment of the percent cove in the two habitats. Perhaps it would be possible to arrive at the conclusion that the two habitats support different populations, if the inclined point quadrat method were used without the basal modification. This would provide indirect information on the herbage production of the two habitats, in addition to the information collected with the basal contact modification. It was observed that the vegetation on the mounds was more luxuriant than in intermound areas (Fig. 2); perhaps this modification of the experiment as performed would accentuate the difference recorded into one significant both

statistically and

biologically.

Summarizing the soil analysis data, mounds and intermounds did not vary significantly in physical composition. Alternatively, it is possible that the soils varied chemically, but such determinations were not made. The soils of mounds and intermounds did vary in depth (Figs. 9 and 10). The difference noted in the percent cover on mounds and intermounds may possibly be attributed to the available water held in each soil. Perhaps the deeper mound soil provided for more extensive root growth, a cooler soil, and greater soil area for storage of available water; in response, mound vegetation exhibited a somewhat higher percent cover and particular species composition. Conversely, the soil depth of intermounds allowed less root growth; provided a warmer soil and less soil space for water storage; thus intermound vegetation was lower in percent cover and contained species adapted to these conditions. If soil depth and its corresponding available water are influential in determining vegetation, it is possible that the difference noted in mound and intermound vegetation was greater this dry year than might normally be the case.

One difference between mounds and intermounds which may be significant is that most mounds were observed to contain the burrows of numerous animals; skunks, field mice and snakes were observed to inhabit mounds. The presence of these animals could influence the vegetation in numerous ways, by providing organic fertilizer to the mounds, changing the carbon dioxide levels of the mound soil, varying the compaction of the soil and displacing the root systems, especially tap roots. Depending on the extent of animal disturbance, the mounds could provide a habitat 
which varied greatly from intermound habitats, a difference which could easily be mirrored by vegetation. The observations and data support some of the general ideas offered in the introduction concerning pimple hills and refute others. The mound soil considered here was definitely not loess-like, but a sandy loam. The soil of mounds and intermounds was physically similar, and revealed similar horizons. There was no evidence to suggest that mounds were formed by animal activity, though animals were present on the study site. That the mounds studied occurred on upland ridges, were composed of sandy soil, and were aligned downslope, support the hypothesis that erosion creates and maintains mounds. Whether this erosion was enhanced by frost or desiccation fissures or tree pedestals were not

determined. Trees do not now occur along the ridges considered; whether they once initiated mound

formation might be elucidated by sectioning the mound to determine residual evidence of roots. Such sections, which would also have aided in estimating the extent of animal activity, were not made on the insistence of the property owner.

Thus it may be said that the prairie considered exhibited a microrelief feature of pimple mounds and intermound regions, but the two soils did not vary in physical composition. These mounds were found to lie in an irregular pattern along an upland ridge with a slight alignment downslope. Mounds supported vegetation which differed in species composition from the vegetation of intermound regions; there was no significant difference in the percent cover by vegetation of these two prairie habitats, though the unassessed data suggested that the mounds were more productive than the intermound prairie. The abnormally low rainfall through the experimental period doubtlessly influenced the results of the vegetation study. Perhaps repetition of the vegetation study, with the modifications proposed herein, during a growing season with more normally distributed precipitation, would produce more reliable results, providing for more conclusive remarks about the vegetation of mounds and intermounds than can be extended here. 
TABLE 1

LIST OF THE VASCULAR PLANTS COLLECTED FROM MARCH THROUGH JULY, 1972, AT THE STUDY SITE LISTED BY FAMILIES (Nomenclature according to U.T. Waterfall (1969); common names according to Gleason (1963) and Rechethin (1954)

\section{Scientific Name}

Graminae

Andropogon Gerardi

Andropogon scoparius

Andropogon ternaries

Bouteloua curtipendula

Bromus japonicus

Cynodon Dactylon

Festuca octoflora

Hordeum pusillum

Lolium multiflorum

Manisuris cylindrica

Panicum oligosanthes var. Scribnerianum

Panicum Ravenelii

Panicum sphaerocarpon

Panicum virgatum

Sorghastrum nutans

sporobolus cryptandrus

Cyperaceae

Carex caroliniana

Cyperus filiculmis

Liliaceae

Camassia scilloides

Erythronium albidum

Nothoscordum bivalve

Amaryllidaceae

Hypoxis hirsute

Orchidaceae

Spiranthes vernalis

Santalaceae

Commandra Richardsoniana

Polygonaceae

Eriogonum longifolium

Portulacaceae

Claytonia virginica

Caryophyllaceae

Arenaria patula

Cerastium vulgatum var.

vulgatum
Common Name

Big blue stem

Little blue stem

Splitbeard blue stem

Side-oats grama

Japanese brome grass

Bermuda grass

Sixweeks fescue

Little barley

Italian rye grass

Carolina jointtail

Scribners panicum

--

Roundseed panicum

Switchgrass

Indian grass

Sand dropseed

Carolina sedge

Slenderleaf sedge

Wild hyacinth, Atlantic camas

Dogtooth violet, white fawn lily

Yellow false-garlic

Stargrass, common goldstar

Upland ladies tresses

Bastard toad-flax

Longleaf wild-buckwheat

Spring beauty

Pitchers sand wort

Mouse-ear chickweed,

Big chickweed

Murray, C.L. 
Ranunculaceae

Anemone virginiana

Delphinium tricornis forma albiflora

Ranunculus hispidus

Cruciferae

Selenia aurea

Saxifragaceae

Saxifraga texana

Leguminoseae

Dalea purpurea

Lotus americanus

Schrankia uncinata

Tephrosia virginiana var.

holosericea

Oxalidaceae

Oxalis corniculata

Oxalis dillenii

Polygalaceae

Polygala incarnate

Polygala sanguinea

Umbelliferae

Eryngium yuccafolium var. synchaetum

Polytaenia Nuttallii var. Nuttallii

Gentianaceae

Sabatia campestris forma campestris

Asclepiadaceae

Asclepias stenophylla

Asclepias veridis

Hydrophyllaceae

Phacelia strictiflora

Labiatae

Scutellaria parvula var. Leonardi

Solanaceae

Solanum carolinense forma carolinense

Scrophulariaceae

Buchnera Americana

Castelleja coccinea var. coccinea

Linaria canadensis var. texana

Penstemon tubaeflorus
Virginia anemone, windflower

Rock larkspur

Bristly buttercup

Yellow selenia

Texas saxifrage

Deervetch

Catclaw sensitive briar

Goats rue, Virginia

tephrosia

Wood sorrel, creeping oxalis

Sheep sorrel, wood sorrel

Pink milkwort

Blood milkwort

Yucca-leafed eryngo

Prairie parsley

Prairie rosegentian

Slimleaf milkweed

Milkweed

Prairie phacelia

small skullcap

Carolina horse nettle

American blueheart

Painted cup, Indian paintbrush

Old-field toadflax

Beard tongue, tube

penstemon 


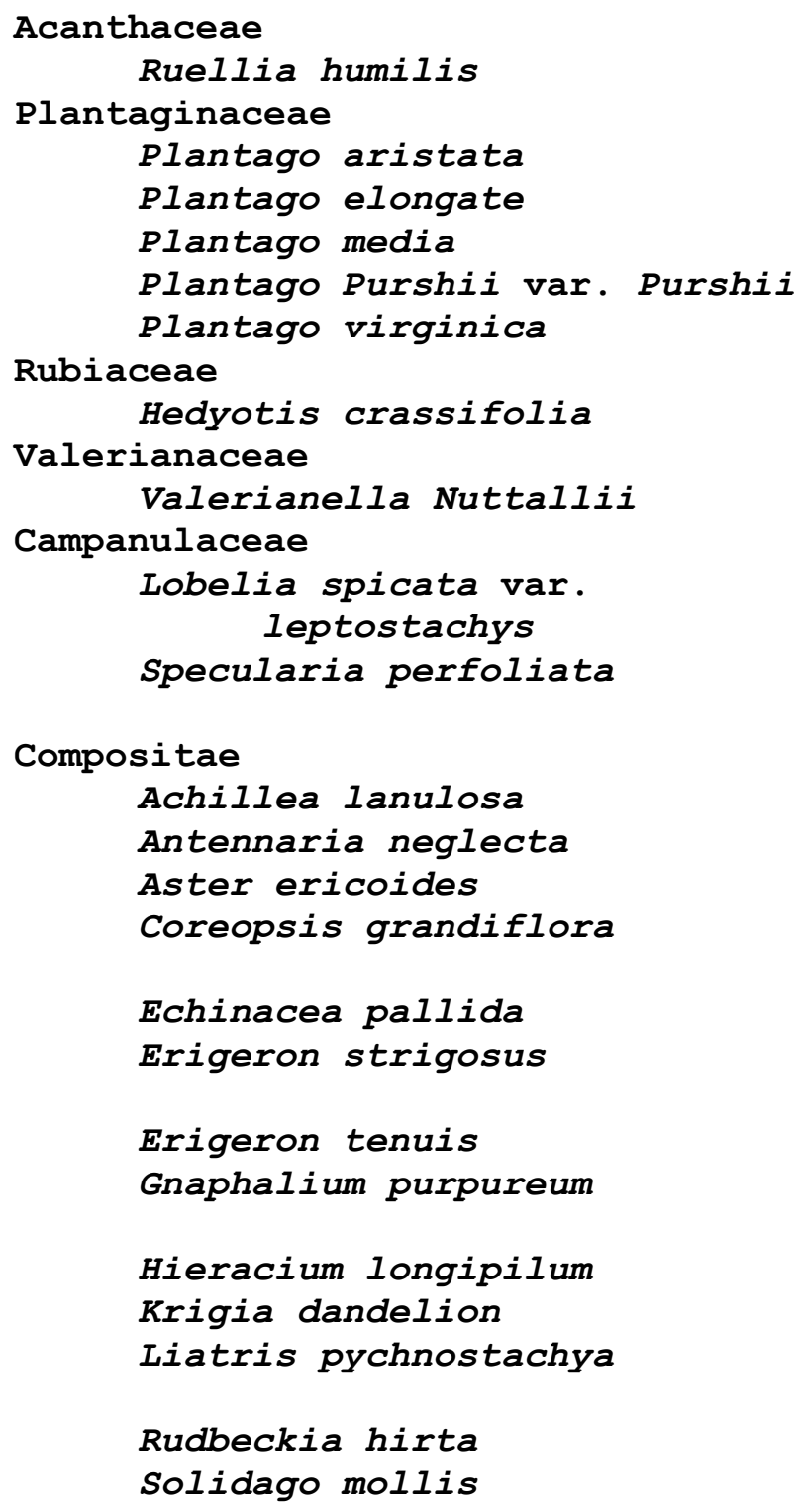

Low ruellia

Bottlebrush plantain

$--$

Wooly plantain

Paleseed plantain

Tiny bluet

Nuttall cornsalad

Palespike lobelia Clasping Venus' lookingglass

Western yarrow Everlasting, pussytoes Wild aster, heath aster Tickseed, big-flower coreopsis

Coneflower, pale echinaceae Daisy fleabane, prairie fleabane

Slender fleabane Cudweed, everlasting, purple cudweed

Longbeard hawkweed Tuber dwarf dandelion Blazing star, Kansas gayfeather Coneflower, blackeyed susan Ashy goldenrod 
TABLE II

PLANTS COLLECTED, NOTING WHETHER THE SPECIES OCCURRED ON MOUNDS, IN INTERMOUND REGIONS, OR BOTH (ASTERISK DESIGNATES IN WHICH HABITAT A SPECIES FIRST BLOOMED)

Mound Species

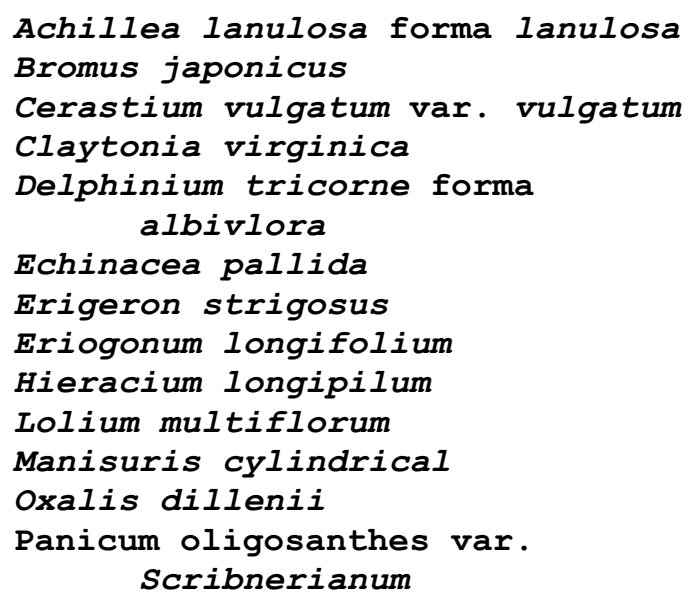

Intermound Species

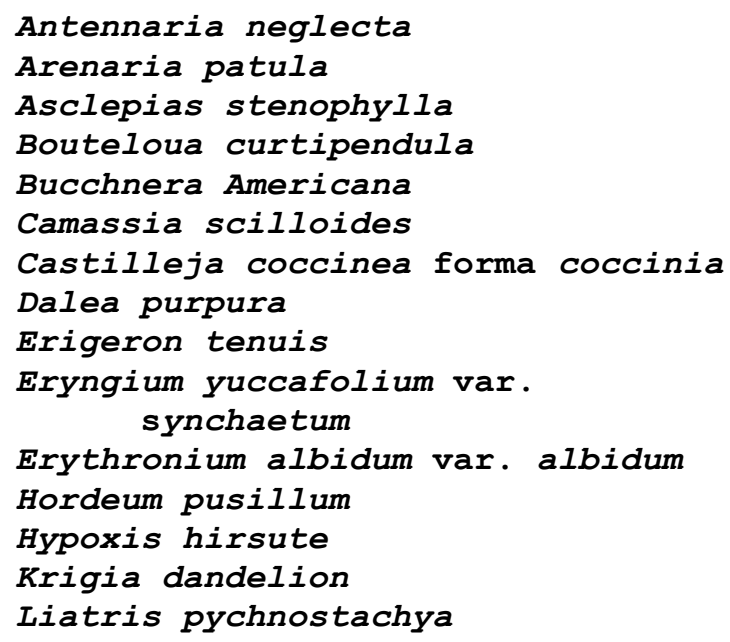

Mound and Intermound Species

\author{
Panicum Ravenelii \\ Panicum virgatum \\ Phacelia strictiflora \\ Plantago aristata \\ Plantago elongate \\ Plantago Purshii var. \\ Purshii \\ Rudbeckia hirta \\ Solanum carolinense forma \\ carolinense \\ Solidago mollis \\ Specularia perfoliata \\ Tephrosia virginiana var. \\ holosericea \\ Valerianella Nuttallii
}

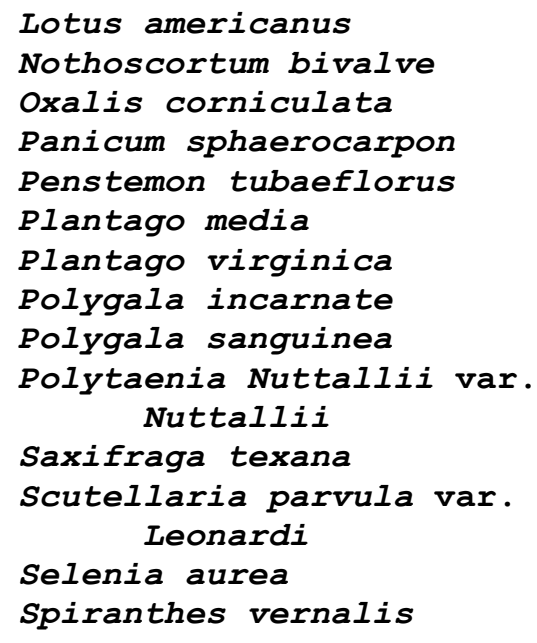

Lotus americanus Nothoscortum bivalve Oxalis corniculata Panicum sphaerocarpon Penstemon tubaeflorus Plantago media Plantago virginica Polygala incarnate Polygala sanguinea Polytaenia Nuttallii var. Nuttallii

Saxifraga texana Scutellaria parvula var. Leonardi

Selenia aurea Spiranthes vernalis

Andropogon Gerardi Andropogon scoparius Andropogon ternaries Anemone virginiana $\star_{M}$ Asclepias viridis Aster ericoides *IM Carex caroliniana Comandra Richardsoniana Coreopsis grandiflora Cynodon dactylon Cyperus filiculmis Festuca octoflora *IM
Gnaphalium purpureum Hedyotis crassifolia Linaria canadensis var. texana *IM

Lobelia spicata var. leptostachys

Ranunculus hispidus Ruellia humilis

Sabatia campestris forma campestris

Schrankia uncinata Sorghastrum nutans Sporobollus cryptandrus 
TABLE III

COMPARISON OF THE PHYSICAL COMPOSITION OF THE SOIL FROM MOUND AND INTERMOUND REGIONS, DETERMINED BY THE BOUYOUCOS METHOD (MOUNDS AND INTERMOUNDS ARE DESIGNATED BY Numbers 1,2,3.

Soil horizons are noted as A, B, C)

\begin{tabular}{|c|c|c|c|c|c|c|}
\hline \multicolumn{2}{|l|}{ MOUND } & \multicolumn{2}{|c|}{ Average } & \multicolumn{2}{|l|}{ Average } & Average \\
\hline & ㅇ Sand & \% Sand & \% Silt & \% Silt & \% Clay & \% Clay \\
\hline $1 \mathrm{~A}$ & 85.2 & & 10.7 & & 4.1 & \\
\hline $2 \mathrm{~A}$ & 78.4 & 80.5 & 14.8 & 13.7 & 6.8 & 5.8 \\
\hline $3 A$ & 77.9 & & 15.6 & & 6.5 & \\
\hline $1 B$ & 85.7 & & 9.4 & & 4.9 & \\
\hline $2 B$ & 79.4 & 83.4 & 9.7 & 8.9 & 10.9 & 7.7 \\
\hline $3 B$ & 85.2 & & 7.6 & & 7.2 & \\
\hline $1 \mathrm{C}$ & 79.0 & & 11.3 & & 9.7 & \\
\hline $2 \mathrm{C}$ & 71.4 & 71.5 & 11.6 & 11.4 & 17.0 & 17.1 \\
\hline $3 C$ & 64.2 & & 11.3 & & 24.5 & \\
\hline
\end{tabular}

\begin{tabular}{|c|c|c|c|c|c|c|}
\hline INTERMOUND & & Averag & & Aver & & Average \\
\hline & \% Sand & \% Sand & \% Silt & \% Silt & \% Clay & \% Clay \\
\hline $1 \mathrm{~A}$ & 79.6 & & 11.5 & & 8.9 & \\
\hline $2 \mathrm{~A}$ & 78.4 & 77.9 & 15.3 & 14.9 & 6.3 & 7.2 \\
\hline $3 \mathrm{~A}$ & 75.7 & & 17.9 & & 6.4 & \\
\hline 1B & 82.0 & & 12.5 & & 5.5 & \\
\hline $2 B$ & 71.6 & 75.3 & 15.4 & 15.9 & 13.0 & 8.8 \\
\hline $3 B$ & 72.2 & & 19.7 & & 8.1 & \\
\hline $1 \mathrm{C}$ & 81.8 & & 11.3 & & 6.9 & \\
\hline $2 \mathrm{C}$ & 50.8 & 58.5 & 13.9 & 14.3 & 35.5 & 27.2 \\
\hline $3 C$ & 42.8 & & 17.8 & & 39.4 & \\
\hline
\end{tabular}




\section{LITERATURE CITED}

Aronow, S. 1972. Personal communication.

Barclay, H.G. 1938. A preliminary report of the ecology of a Drosera meadow. Proc. Okla. Acad. Sci. $18: 22-25$.

Blair, W.F. and T.H. Hubbell. 1938. The biotic districts of Oklahoma. Am. Midland Naturalist. 20:425454.

Bouyoucos, G.J. 1936. Directions for making mechanical analyses of soils by the hydrometer method. Soil Sci. 42:225-229.

Branner, J.C. 1905. Natural mounds or "hog wallows". Science, $\mathrm{n}$. ser. 21:514-516.

Cain, R.H. 1974. Pimple mounds: a new viewpoint. Ecology 55 (1) : 178-182.

Campbell, M.R. 1906. Natural mounds. J. Geol. $14: 707-714$

Curry, B.R. 1970. Climate of Oklahoma. U.S. Dept of Commerce Climatography of the United States Nol. 60-34. Rev. ed. U.S. Govt. Printing Office, Washington, D.C.

Dalquest, W.W., and V.B. Scheffer. 1942. Origin of the Mima mounds of western Washington. J. Geol. 50:68-84.
Drew, W.B. 1944. Studies on the use of the point quadrat method of botanical analysis of mixed pasture vegetation. J. Agr. Res. 69:289-297.

Downie, N.M., and R.W. Heath. 1974. Basic statisticsl methods. $4^{\text {th }}$ ed. Harper and Row, Publishers, New York, Evanston, San Francisco and London. $335 \mathrm{p}$.

Fenneman, N.M. 1931. Physiography of eastern United States. McGraw-Hill Book Company, New York. 714 $\mathrm{p}$.

Gleason, H.A. 1963. The new Britton and Brown illustrated flora of the northeastern United States and adjacent Canada. $3^{\text {rd }}$ print., slightly rev. Hafner Publishing Company, Inc., New York and London. $3 \mathrm{v}$.

Grant, C. 1948. Mima mounds. J. Geol. 56:229-231.

Knechtel, M.M. 1952. Pimpled plains of eastern Oklahoma. Geol. Soc. Amer. Bull. 63:689700 .

Krinitsky, E.L. 1949. Origin of pimple mounds. Am. J. Sci. 247: 706-714.

LeConde, J. 1874. On the great lava flood of the Northwest and on the structure and age of the Cascade Mts. 
Am. J. Sci. Ser.

$3,7: 259-367$.

McGinnies, W. 1960. Effect

of Mima-type

microrelief on herbage

production of five

seeded grasses in

western Colorado. J.

Range Management.

13 ( 5 ) : 213-234.

Melton, F.A. 1929. Natural

mounds of northeastern

Texas, southern

Arkansas, and northern

Louisiana. Proc. Okla.

Acad. Sci. 9:119-130.

- 1954. Natural

mounds of northeastern

Texas southern

Arkansas and northern

Louisiana. The Hopper,

Oklahoma Geol. Surv.

14:88-121. Privately

published.

Prescott, J.A. 1931. The

soils of Australia in

relation to vegetation

and climate.

Commonwealth of

Australia, Council for

Scientific and

Industrial Research

Bull. 52. 71 p.

Rechethin, C.A. 1954.A

guide to plant names

in Texas, Oklahoma,

Louisiana and

Arkansas. Rev. ed.

U.S. Dept. Agr., Soil

Conservation Service,

Fort Worth. $91 \mathrm{p}$.

Ross, B.A., J.R. Tester, and

W.J. Breckenridge.

1968. Ecology of Mimi-

type mounds in northwestern

Minnesota. Ecology

$49(1): 172-177$.

Scheffer, V.B. 1958. Do

fossorial rodents

originate Mima-type

microrelief. Am.

Midland Naturalist.

59:505-510.

Tinney, F.W., O.S. Aamodt, and H.L. Ahlgren.

1937. Preliminary

report of a study on

methods used in

botanical analysis of

pasture swards. J. Am.

Soc. Agr. 29:835-840.

Veatch, A.C. 1906. On

thehuman origin of

small mounds of the

lower Mississippi

Valley and Texas.

Science. $23(575): 34-$

36 .

Waterfall, U.T. 1969. Keys

to the flora of

Oklahoma $4^{\text {th }}$ ed.

Stillwater. Privately

published.

Whitman, W.C., and E.I. Siggeirsson. 1954.

Comparison of line

intercept and point

contact methods in the

analysis of mixed

grass range

vegetation. Ecology

35:431-436.

Winer, B.J. 1962 .

Statistical principles

in experimental

design. McGraw-Hill

Book Company, New

York. Chapter 7. p

302-313. 